\title{
EFFECT OF COPPER COATED LUPINE EXTRACT NANOPARTICLES ON SOME AQUATIC AND TERRESTRIAL PEST SNAILS
}

\author{
Karima M. Azzam, Eman Abdel-Hady and Eman K. Khedr \\ Plant Protection Research Institute, ARC, Dokki, Giza, Egypt \\ *Corresponding author: mnmn7733@yahoo.com \\ Accepted 9 October, 2019
}

\begin{abstract}
Effect of lupine extracts nanoparticles (NPs) coated with copper sulphate on the mortality and eggs productivity of aquatic snails, Biomphalaria alexandrina Ehrenberg and Bulinus truncatus Audouin, and terrestrial snail, Eobania vermiculata Müller, were investigated in comparison with copper sulphate nanoparticles and both treatments compare with untreated group in the present and previous investigation.

This experiment was planned to elucidate the molluscicidal properties of lupine extract coated with CuSO4 NPs against adult $B$. alexandrina $B$. truncatus and $E$. vermiculata snails after 24 hours exposure, in dark conditions, followed by another $48 \mathrm{hrs}$. light for recovery.

The results revealed that lupine extracts nanoparticles has more effect than copper sulphate nanoparticles on both aquatic or terrestrial snail mortality. It caused $100 \%$ mortality for $B$. alexandrina and $B$. truncates, at concentration of $20 \mathrm{ppm}$, after 24 hours of exposure in dark followed by 48 hours recovery in day light. Copper sulphate nanoparticles at the same concentration caused only $70 \%$ and $46.67 \%$ mortality for B. alexandrina and $B$. truncates, respectively, under the same conditions. Mortality rate increased with the increase of concentrations either in lupine NPs or $\mathrm{CuO}_{4} \mathrm{NPs}$. On normal lupine extract the concentration that caused $100 \%$ mortality was equal to ten folds of lupine NPs.

Egg productivity of the healthy thirty individuals, of $B$. alexandrina, B. truncatus and E. vermiculata, were investigated and compared with the survival snails in low concentrations of both $\mathrm{Cu}$ NPs and lupine NPs, to study the effect of nanoparticle materials on the snail fecundity.
\end{abstract}

Both lupine extract nanoparticles and copper sulphate nanoparticles may have a sterilized effect, where $B$. alexandrina and $B$. truncatus snails exposed to sub lethal doses from them didn't laid any egg masses after treatment. E. vermiculata, treated or untreated individuals, didn't laid any eggs either, because it had a specific season of reproduction which not coinciding with the time of experiment

Keywords: Lupine coated copper NPs, Aquatic snails, Terrestrial snail

\section{INTRODUCTION}

Gastropods are very prevalent animals in the world (Barker, 2002). In Egypt, terrestrial snails are important economic pests, prevalent in many Governorates, infesting and causing severe damage to many economic agricultural crops i.e., orchard trees, vegetables and field crops and ornamental plants (Desoky, 2018). Azzam and Abd El-Hady (2018) recorded seven snail species and three slug species infesting about 47 species of plants in seven Governorates in Egypt, including Cairo and Arish (North Sinai). All terrestrial snails cause damage to their host plants, by feeding on leaves, blooms, flowers, fruits, trunks, limbs and even on barks (Godan, 1983 and Ismail et al 2003).

Azzam and Belal (2006) recorded 20 aquatic molluscs species; including the snails playing as an intermediate hosts of Schistosoma mansoni Sambon, Schistosoma heamatobium Bilharz, Fasciola gigantica Cobbold, F. hepatica L. and Angiostrongylus cantoniensis Chen. Thus, snail control strategies are considered a priority for preventing or minimizing Schistosomiasis transmission (Lardans and Dissous, 1998) as well as reducing damage to economic agricultural crops in Egypt. 
These emphasized the necessity of controlling such harmful terrestrial and aquatic snails which predominately achieved by the application of molluscicides which lead to more environmental pollution. However, further innovated techniques are required in this field.

Nanoparticles are naturally occurring in both aquatic and terrestrial environments in form of colloids, "mineral precipitates ( $\mathrm{Al}, \mathrm{Fe}, \mathrm{MgO}, \mathrm{OH})$ " and dissolved organic matter" (Boverhof et al 2015). The development of nanotechnology produces many nanoparticles (NPs) that are important in medicine, agriculture and industry (Grazyna et al 2014). Fernandes et al (2007), suggested that ENPs may affect organisms' behavior, survivorship, and community structure, function and biogeochemical processes.

El-Tarky (2005) noticed that, mortality rate of adult $B$. alexandrina snails was $52 \%$, when exposed for $4 \mathrm{hrs}$ to $438.8 \mathrm{w} / \mathrm{m} 2$ of sunlight after 12 hours of their incubation with 10-5 Hpds.. The author added that, the effect of Hpds against snails increased in the alkaline media $(\mathrm{pH}=8)$, while decreased at the acidic ones $(\mathrm{pH}=6)$. It was stated that porphyrins and their derivatives exhibited a potent phytotoxic effect against gram-positive bacteria. Ragheb (2009) stated that, incubation of $B$. truncatus snails, for $24 \mathrm{hrs}$ at $10-4 \mathrm{M} / \mathrm{L}$ gold nanoparticles (GNPs) in dark, followed by 2 hours of exposure to $650 \mathrm{~W} / \mathrm{m} 2$ irradiance (Solar Simulator), resulted in $100 \%$ death.

El-Hommossany and El-Sherbibni (2011) mentioned that, exposed $B$. alexandrina to $5 \times 10$ $5 \mathrm{Mdm}-3$ (HpdGNPs) with 4 hours of exposure to sunlight suppressed the survival rate of $B$. alexandrina snails by $50 \%$. Meanwhile, control snails incubated with $5 \times 10-5 \mathrm{Mdm}-3 \mathrm{HpdGNPs}$ were not affected and still alive (100\%). They also found that exposing $B$. alexandrina snails to sub lethal concentrations of the photosensiter Hpd coated GNPs (12 hours incubation, 4 hours exposure to $336.2 \mathrm{~W} / \mathrm{m} 2$ ) significantly reduced their reproductive capacity.

Nanomaterial toxicological studies have also shown large bactericidal and mutagenic effects due to the metal ion properties, stabilizing agents and the size and shape of the NMs (Suresh et al 2013). Fish and plants were seen to show an inhibited growth, and even death when coming into contact with specific nanoparticles (Burke et al 2015). However, some conflicting data exist where plants have shown improvement in growth under specific exposure (Lahiani et al 2013).
Adult blue mussels, Mytilus edulis, exposed to $0.7 \mu \mathrm{g} \mathrm{L}-1 \mathrm{Ag}$ NPs exhibited shell abnormalities after 72 hours, and $50 \%$ of snails, Lymnaea luteola, died after 96 hours of exposure to $48 \mu \mathrm{g} \mathrm{L}-1 \mathrm{Ag}$ NPs (Wong et al 2013; Ali et al 2014). The 96hour LC50 of Ag NPs for gastropods decreased from $2.18 \mu \mathrm{g} \mathrm{L}-1$ in the absence of sediment to $>100 \mu \mathrm{g} \mathrm{L1}$ when sediment was present (Bernot et al 2013).

Copper compounds have been used as molluscicides. Shaldoum et al (2016), studied the immunological effect of $\mathrm{Cu}_{2} \mathrm{O}$ nanoparticles on Biomphalaria alexandrina snails.

Nanotechnology is used to modify material at the nano-scale $(<100 \mathrm{~nm})$ to create novel properties. Changes in the physicochemical and structural properties of materials caused by the decrease in particle size can lead to new and sometimes unexpected biological effects. Besnaci et al (2016), evaluated the toxicity of $\mathrm{Fe} 2 \mathrm{O} 3$ nanoparticles on the embryonic stage of Helix aspersa with different concentrations $(1.25 \mathrm{mg} / \mathrm{ml}, 1.5 \mathrm{mg} / \mathrm{ml}$, and $2 \mathrm{mg} / \mathrm{ml}$ ). Ali et al (2015), evaluate the possibilities of using silver nanoparticles (Ag NPs) to control the land snail Eobania vermiculata Muller.

Saddik et al. (2017), found that 10.7 (mg/L) of ZnNPs. caused $90 \%$ mortality of Oreochromis niloticus after $24 \mathrm{hrs}$, while 10.99 (mg/L) of it caused the same ratio of mortality from Tilapia zillii fish. Organ failure was observed in zebra fish and carp due to acute exposure to metal NPs (Griffit et al 2008). Human organs can also be severely affected by inhaling, ingesting or coming into contact with large amounts of nanomaterial (Tang et al 2015). Nanomaterials have been shown to enter living organisms and "exert toxic effects at the cellular level, including membrane disruption, protein inactivation, DNA damage, and disruption of energy transfer and release of toxic substances (Van Aken, 2015). The effect of chitosan and nanochitosan on the land snails Eobania vermiculata and Monacha obstructa was investigated by Khidr (2018).

To equilibrate between the advantage and disadvantage of metal nanoparticles in the present study, evaluation of the effects of Lupine coated cupper nanoparticles on the terrestrial and aquatic snails was made as a mean of control, to reduce the toxicological effect of copper metal nanoparticles on environment and at the same time control the harmful snails. 


\section{MATERIALS AND METHODS}

Rearing of the terrestrial snail (E. vermiculata) and aquatic snails ( $B$. alexandrina and $B$. truncates) were carried out by the technique previously described by Azzam and Tawfik (2005).

\section{Lupine-coated cupper nanoparticles}

\section{Lupine Extract}

Preparing extracts was conducted by grinding the grain of lupine until getting a fine powder, then placed it in two flasks each containing $500 \mathrm{gm}$ of lupine powder. The powder was soaked in ethanol for 48 hours (two centimeter height above the powder surface). The extracted solution was evaporated by rotary evaporator until complete dryness, then weighted and solved in certain amount of ethanol to prepare the stock solution.

\section{Chemicals}

Copper Sulphate $\left(\mathrm{CuSO}_{4} .5 \mathrm{H}_{2} \mathrm{O}\right), 98 \%$, product of Adwic Chemika Co., Glucose $\left(\mathrm{C}_{6} \mathrm{H}_{12} \mathrm{O}_{6}\right.$, with average molecular weight $=180.2$ ) product of $\mathrm{El}$ Nasr Pharmaceutical Chemicals Co., Starch soluble $99 \%$ powdered solid $\left(\left(\mathrm{C}_{6} \mathrm{H}_{10} \mathrm{O}_{5}\right) \mathrm{n}\right.$, with average molecular weight $=81.37)$ product of Chemajet Pharmaceutical Co.

\section{Synthesis of starch-copper nanoparticle- encapsulated}

Starch-copper nanoparticle-encapsulated formulated according to (Ihegwuagu et al 2016), with the modification that encapsulation was completed in situ during synthesis of the copper nanoparticles by direct physical gelation (Ihegwuagu et al 2016 and Tali, 2009). The synthesis was carried out via chemical reduction of Copper sulphate by glucose as follows: to a mixture of $5 \%$ CuSO $4.5 \mathrm{H} 2 \mathrm{O}$ and $0.2 \mathrm{M}$ glucose solution (1: 3 volume ratio) in a loosely covered flask containing $1 \%$ starch dispersion (1 $\mathrm{g}$ in $100 \mathrm{ml}$ distilled water), then added 10 $\mathrm{ml}$ of (lupine extract). This formulation was stirred and heated at $80-90^{\circ} \mathrm{C}$ in a fume cupboard for 3 hours. Heating was stopped and stirring continued till cooling to room temperature then centrifuged at 11000 rpm for 20 minutes.

A similar procedure was performed for the preparation of the control (CuSO4.5H2O) without adding lupine extract.

\author{
Characterization of Lupine and $\mathrm{CuO}_{4}$ nanopar- \\ ticles
}

Particle size and size distributions were determined by a Malvern Zetasizer 3000 HAS Nano s. England (Malvern Instruments) Figs. (1 \& 2).

\section{Molluscicidal effect of Lupine coated cupper nanoparticles}

The present experiment was carried out by preparing six replicates of gradual concentrations from each stock solution, for each concentration, then applied on the terrestrial species (Eobania vermiculata) and the two aquatic species (Biomphalaria alexandrina and Bulinus truncatus). Five snails, $8-10 \mathrm{~mm}$ diameter from $B$. alexandrina, $9-11 \mathrm{ml}$ heights from $B$. truncatus and $20-22 \mathrm{ml}$ widths from $E$. vermiculata, were used in each replicate. The snails were exposed to the tested concentrations $(1.25,2.5,5,10$ and 20 PPM of lupine NPs coated with $\mathrm{Cu} \mathrm{So} 4$ ) for 24 hours under dark conditions, then removed from the experimental concentration, washed thoroughly and kept in dechlorinated tap water for the next 24 \& 48 hours for recovery $\left(25 \pm 1^{\circ} \mathrm{C}\right)$. Similar groups were treated with Cu So ${ }_{4}$ NPs and unexposed snails (control) were assayed simultaneously as treated groups.

Snails that did not respond to a gentle prodding with forceps were considered to be dead (Musee et al 2010). The toxicological endpoints measured were; the mortality rates after 24,48 and 72 -hrs. of exposure. Dead snails were recorded as the average of the six replicates.

The effectiveness of the different concentrations was expressed in terms of LC 25, LC 50 and LC 90. Slope of regression lines were represented and analyzed by Chi-square value. Statistical analysis with $\mathrm{LC}_{50}$, $\mathrm{LC}_{90}$, and slope values were based on LDP line program.

\section{Effect of Lupine coated cupper nanoparticles on snail's productivity}

Survival snails in low concentrations from both Cu NPs and Lupine NPs were maintained in laboratory until death to investigate its capability to laying egg masses, for aquatic snails, and eggs in terrestrial snails, in comparison with untreated snails. The snails were daily fed on fresh lettuce. 


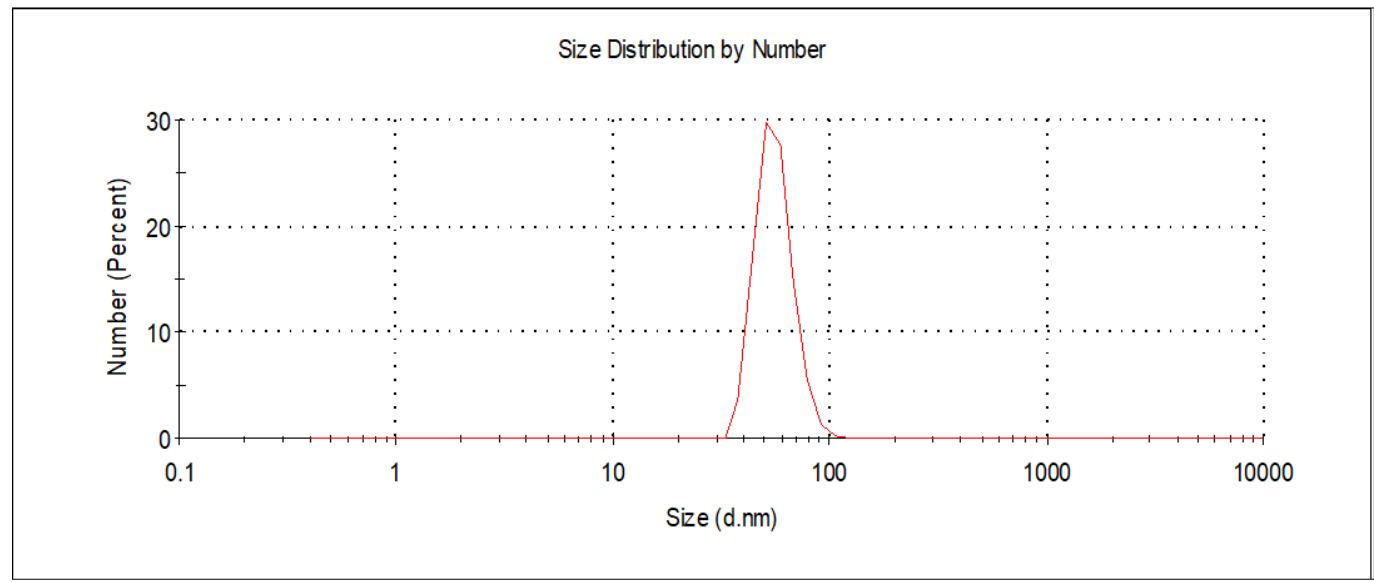

Fig. 1. Size of lupine extract NPs coated with copper

Size Distribution by Number

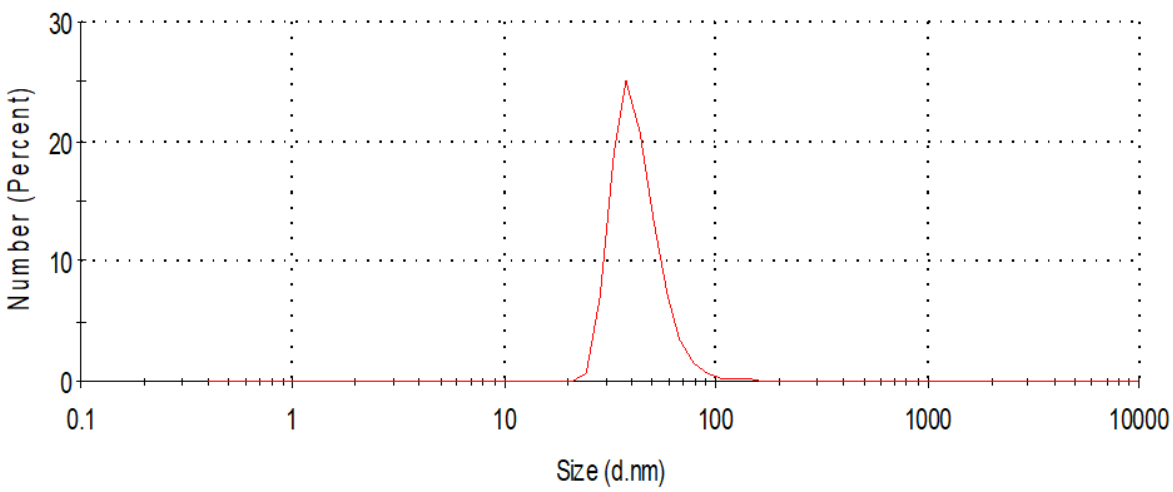

Fig. 2. Size of $\mathrm{CuO}_{4} \mathrm{NPs}$

The numbers of eggs/snail were recorded weekly for four weeks.

Each bioassay was conducted at approximately $22-26^{\circ} \mathrm{C}$, and a $24 \mathrm{~h}: 48 \mathrm{~h}$ dark: light: photoperiod.

\section{Statistical Analysis}

Survival rates of treated snails were analyzed by ANOVA and T test values of contingency tables using SSp statistical program. Concentrations were considered to be toxic if a given test endpoint, namely survival and reproduction, were statistically different from those of the control tested organisms $(P<0.05)$, and at least $20 \%$ lower than the mean tested organism response in the negative control sample (Thursby et al 1997).

\section{RESULTS AND DISCUSSION}

\section{Toxicity test}

This experiment was planned to elucidate the molluscicidal properties of lupine extract coated with CuSO4 NPs against adult $B$. alexandrina, $B$. truncatus and $E$. vermiculata snails after 24 hours of exposure, in dark conditions, followed by another 48 hrs., light for recovery.

Data presented in Table (1) show mortality of $B$. alexandrina and. $B$. truncatus snails treated with tested lupine NPs carrying on CuSO4 NPs concentrations $(1.25,2.5,5,10$ and 20 ppm) in comparative with those exposed to the same concentrations from CuSO4 NPs. The unexposed group (control) shows no mortality, therefore excluded from the tables. 


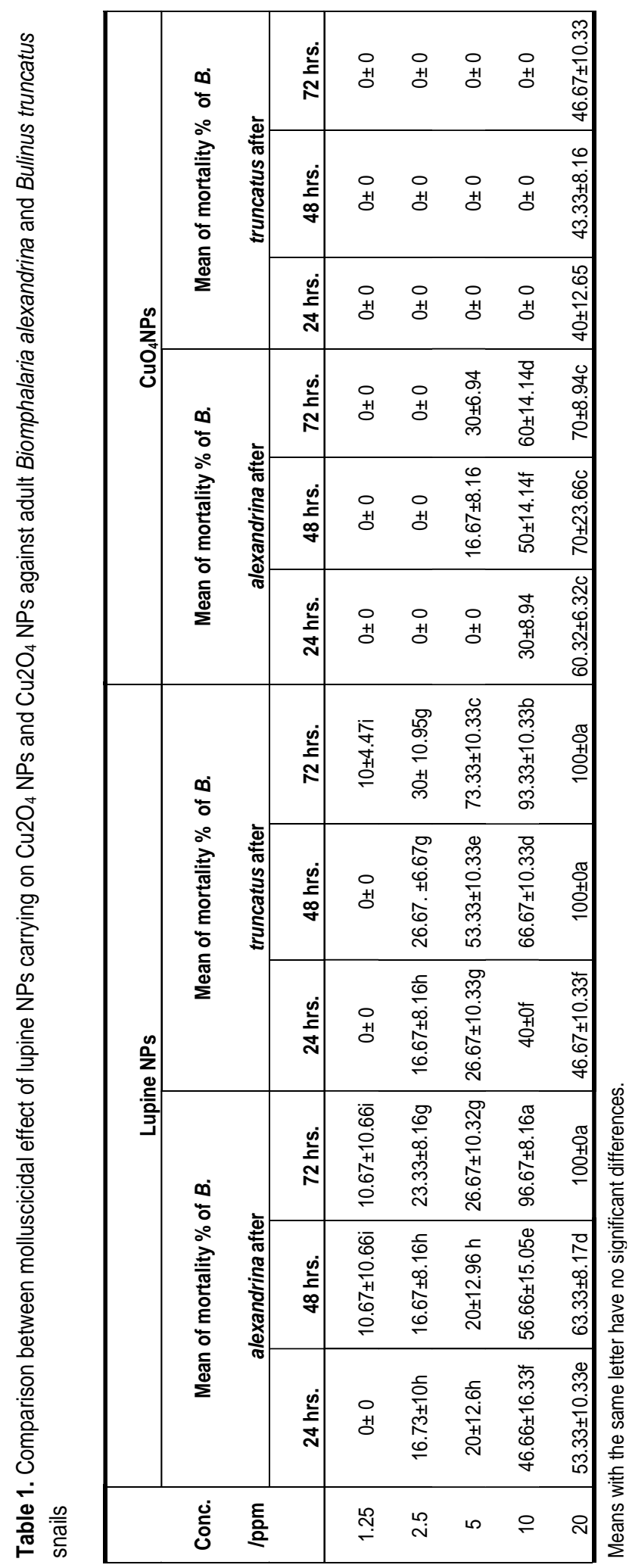


It was noted that both lupine NPs and CuSO4 NPs were agglomerated on the mantle and shell opening of $B$. alexandrina and. $B$. truncatus snails (Figs. 3 \& 6). Musee et al (2010) reported agglomerated $\mathrm{C}-\mathrm{TiO} 2$ nanoparticles attached to the egg mass of Physa acuta Draparnaud.

As seen in this table, the concentration 20 ppm caused $100 \%$ mortality at 72 hrs., in both adults of $B$. alexandrina and $B$. truncates, with very highly significant differences between them and other concentrations, and the concentration at different times in the case of lupine extracts.

In a previous investigation, on normal lupine extract, Azzam et al (2014) recorded 100\% mortality of $B$. alexandrina after $72 \mathrm{hrs}$. at concentration of 200 ppm which equal to ten folds of Lupine NPs that gave the same result. Also, the same authors recorded $1250 \mathrm{ppm}$ for $100 \%$ mortality of $B$. truncatus after $48 \mathrm{hrs}$. Which was more than fifty folds of Lupine NPs that gave the same result in this study.

Also, very highly significant differences were found between results of lupine NPs and $\mathrm{CuO}_{4} \mathrm{NPs}$ at different concentration. Insignificant differences were recorded between other data. No mortality occurred in $B$. truncatus exposed to CuO4NPs concentrations of $10,5,2.5$ and $1.25 \mathrm{ppm}$, while for $B$. alexandrina, no mortality occurred at concentrations of 2.5 and $1.25 \mathrm{ppm}$ only. Shaldoum et al (2016), found that 2.29 ppm of Cu2O NPs killed $90 \%$ from adult $B$. alexandrina. Fahmy et al (2014) found that $2.7(\mathrm{mg} / \mathrm{L})$ of $\mathrm{Zn} \mathrm{NPs}$ killed $90 \%$ of $B$. alexandrina snails. El-Hommossany and ElSherbibni (2011), found that $5 \times 10-5 \mathrm{Mdm}-3$ (HpdGNPs) with 4 hours of exposure to sunlight suppressed the survival rate of $B$. alexandrina snails by $50 \%$. Wong et al (2013) reported that,
$50 \%$ of the snail Lymnaea luteola, died after 96 hours of exposure to $48 \mu \mathrm{g} \mathrm{L-1}$ Ag NPs.

Table (1) also showed that mortality rate increased with the increase of concentrations either in lupine NPs or $\mathrm{CuO}_{4} \mathrm{NPs}$.

Statistically, high correlation was found between concentration and mortality $(r=0.85)$ in the case of Lupine NPs on B. alexandrina and $(r=$ 0.99) on $B$. truncatus with $\mathrm{Chi}^{2}=47.93$.

Mortality of the terrestrial snail E. vermiculata exposed to lupine NPs. and $\mathrm{CuO}_{4} \mathrm{NPs}$. at different concentrations (2, 1.0, 0.5 and $0.25 \%)$ were recorded in Table (2). As seen in this table, the highest rate of mortality (93.33\%) was recorded at the concentration of $2 \%$ of lupine NPs. after $72 \mathrm{hrs}$., while the lowest rate (20\%) was recorded at concentration of $0.25 \%$. No mortality occurred at the concentration of 0.125 of lupine NPs., and all the other concentrations of $\mathrm{CuO}_{4} \mathrm{NPs}$. Statistically, highly significant differences $(P>0.001)$ were recorded between data reported for concentration $2 \%$ and $1 \%$ at $24 \mathrm{hrs}$., and those reported at 48 and 72 hrs. Also highly significant differences $(P>0.001)$ were recorded between different concentrations, but insignificant differences existed between the concentrations $1 \%$ and $0.5 \%$ at 48 and $72 \mathrm{hrs}$. Ali et al (2015) found that, the exposure of the snails E. vermiculata to Ag NPs in a laboratory experiment reduced the activity and the viability of the land snail (20\% of Ag NPs treated snails died).

Khidr, (2018) also, reported significant increasing of mortality rate of $E$. vermiculata with the increase of concentrations of chitosan NPs.

Table (2) also showed significant correlations between concentrations and rate of mortality in the three snail species either in lupine NPs or $\mathrm{Cu}$ NPs.

Table 2. Comparison between the effect of lupine extracts NPs and $\mathrm{CuO}_{4} \mathrm{NPs}$ on Terrestrial snails, Eobania vermiculata as mortality rates under $25 \pm 2^{\circ} \mathrm{C}$

\begin{tabular}{|c|c|c|c|c|c|c|}
\hline \multirow[t]{2}{*}{$\begin{array}{c}\text { Concentration } \\
\%\end{array}$} & & $\begin{array}{l}\text { Lupine NPs } \\
\text { an of mortality } \\
\text { vermiculata aft }\end{array}$ & & $\begin{array}{r}\text { Mean } \\
v e \\
\end{array}$ & $\begin{array}{l}\mathrm{CuO}_{4} \mathrm{NF} \\
\text { of morte } \\
\text { miculat }\end{array}$ & $\begin{array}{l}\text { ty } \% E . \\
\text { after }\end{array}$ \\
\hline & 24hrs. & 48 hrs. & 72 hrs. & 24hrs & $48 \mathrm{hrs}$. & $72 \mathrm{hrs}$. \\
\hline 0.125 & $0 \pm 0$ & $0 \pm 0$ & $0 \pm 0$ & $0 \pm 0$ & $0 \pm 0$ & $0 \pm 0$ \\
\hline 0.25 & $0 \pm 0$ & $20 \pm 6.32 e$ & $20 \pm 6.32 e$ & $0 \pm 0$ & $0 \pm 0$ & $0 \pm 0$ \\
\hline 0.5 & $20 \pm 5.16 \mathrm{e}$ & $56.67 \pm 23.38 c$ & $56.67 \pm 23.38 \mathrm{c}$ & $0 \pm 0$ & $0 \pm 0$ & $0 \pm 0$ \\
\hline 1 & $36.67 \pm 15.06 d$ & $60 \pm 7.3 c$ & $60 \pm 7.3 c$ & $0 \pm 0$ & $0 \pm 0$ & $0 \pm 0$ \\
\hline 2 & $80 \pm 10.33 b$ & $93.33 \pm 6.67 a$ & $93.33 \pm 6.67 \mathrm{a}$ & $0 \pm 0$ & $0 \pm 0$ & $0 \pm 0$ \\
\hline
\end{tabular}

Means with the same letter have no significant differences 

and Terrestrial Pest Snails

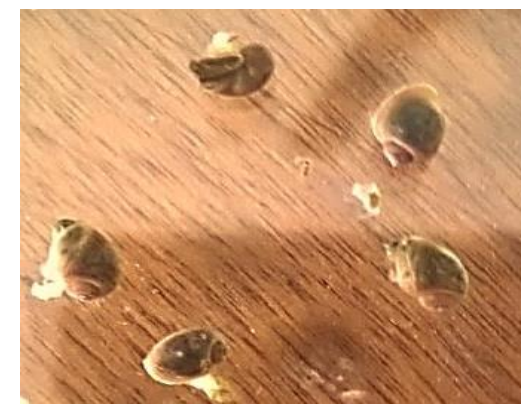

Fig. 3. Agglomeration of lupine NPs on the mantle and opening of $B$. truncatus snails

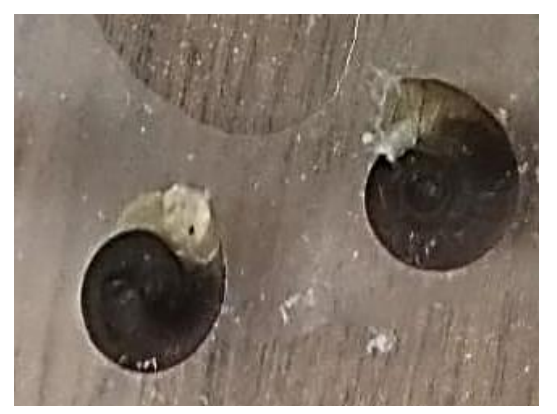

Fig. 5. Agglomeration of lupine NPs on the mantle and opening of $B$. alexandrina snails

\section{Effect of Lupine coated cupper nanoparticles on snail productivity}

To study the effect of nanoparticle materials on the snail fecundity, egg productivity of the healthy thirty individuals of $B$. alexandrina, $B$. truncatus and $E$. vermiculata, were investigated and compared with the survival snails in low concentrations from both $\mathrm{Cu}$ NPs and lupine NPs. Results were summarized in Table (3).

As seen in this table, the terrestrial snail $E$. vermiculata hadn't laid any eggs either for treated or untreated individuals because it had a specific season of reproduction which was not coinciding with the time of the current experiment. Healthy or untreated individuals of both $B$. alexandrina and $B$. truncatus laid $3 \pm 0.71$ and $3.6 \pm 0.89$ egg masses/ snail, respectively. Each contained $11.47 \pm 2.2$ and $10.44 \pm 2.01$ eggs/mass, respectively. While the treated individuals from both species, either with lupine NPs or Cu NPs, didn't laid any eggs throughout the recovery period. Thus nanoparticles may affect the fecundity of the snails.

El-Hommossany and El-Sherbibni (2011) found that, $5 \times 10-5 \mathrm{Mdm}-3$ (HpdGNPs) with 4

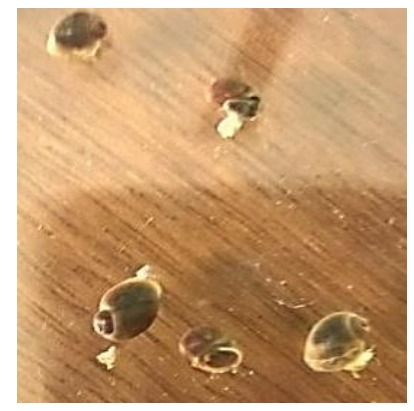

Fig. 4. Agglomeration of CuSO4 NPs on the mantle and opening of $B$. truncatus snails

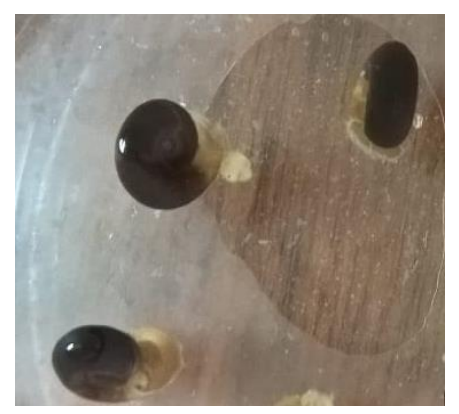

Fig. 6. Agglomeration of CuSO4 NPs on the mantle and opening of $B$. alexandrina snails

hrs. of exposure to sunlight, treated snails laid low number of eggs throughout the recovery period (4 weeks), in comparison with that of control ones. Musee et al (2010) indicated that an increase in calumina and a-alumina NPs concentrations caused a significant decrease $(P<0.01)$ in the percentage of embryo hatched for Physa acuta snail as well as number of egg masses and eggs. But none of the different concentrations of $\mathrm{TiO} 2$, commercial $\mathrm{TiO} 2$, c-alumina and a-alumina prevented egg lying. Besnaci et al (2016), revealed a deformation of egg membrane and accumulation of this molecule at the back of the egg. They also noted a low rate of hatching in the 12th day, and the mortality rate is found to be high at the highest concentration of $\mathrm{Fe} 2 \mathrm{O} 3$.

The same table showed significant differences between values of $\mathrm{LC}_{25}, \mathrm{LC}_{50}$ and $\mathrm{LC}_{90}$, of $B$. alexandrina treated with lupine NPs, and those treated with $\mathrm{CuO} 4 \mathrm{NPs}$. Whereas, the $\mathrm{LC}_{90}$ value recorded in the case of $\mathrm{CuO}_{4} \mathrm{NPs}$ was equal to more than four folds than that recorded for lupine NPs. These indicated that lupine NPs was more effective than $\mathrm{CuO}_{4} \mathrm{NPs}$. Thus it could be conclude that lupine NPs enhanced the effect of $\mathrm{CuO}_{4} \mathrm{NPs}$. 


\begin{tabular}{|c|c|c|c|c|}
\hline \multirow{4}{*}{ 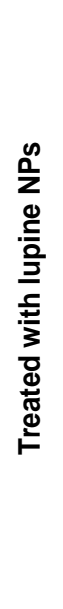 } & 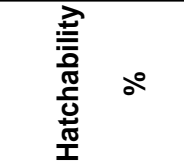 & 0 & 0 & 0 \\
\hline & 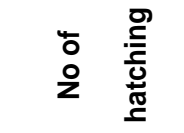 & 0 & 0 & 0 \\
\hline & 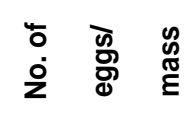 & 0 & 0 & 0 \\
\hline & 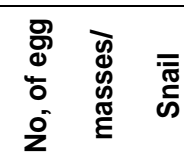 & 0 & 0 & 0 \\
\hline \multirow{4}{*}{ 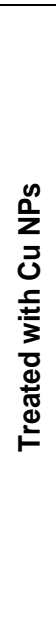 } & 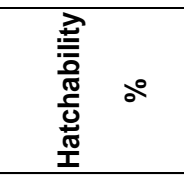 & 0 & 0 & 0 \\
\hline & 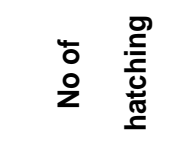 & 0 & 0 & 0 \\
\hline & 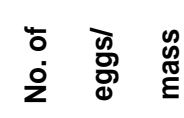 & 0 & 0 & 0 \\
\hline & 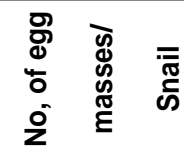 & 0 & 0 & 0 \\
\hline \multirow{4}{*}{ 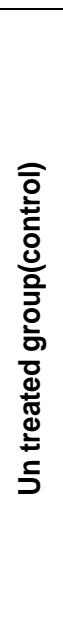 } & 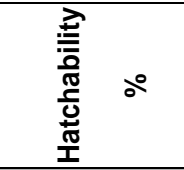 & $\begin{array}{l}\hat{} \\
\dot{\sigma}\end{array}$ & $\begin{array}{l}\bar{f} \\
\stackrel{8}{o}\end{array}$ & 0 \\
\hline & 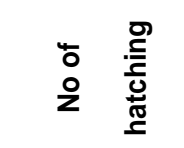 & 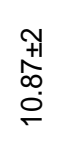 & 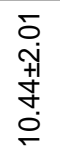 & 0 \\
\hline & 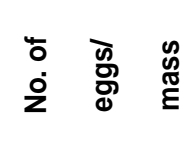 & \begin{tabular}{l}
$\underset{N}{\sim}$ \\
+1 \\
\multirow{+}{*}{} \\
$\check{E}$
\end{tabular} & $\begin{array}{l}\bar{\sigma} \\
\dddot{i} \\
\infty \\
\infty \\
0 \\
0\end{array}$ & 0 \\
\hline & 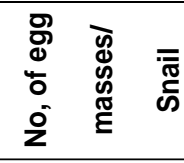 & $\begin{array}{l}\Gamma \\
\hat{0} \\
+1 \\
0\end{array}$ & $\begin{array}{l}0 \\
0 \\
0 \\
+1 \\
0 \\
\infty \\
\dot{\infty}\end{array}$ & 0 \\
\hline & 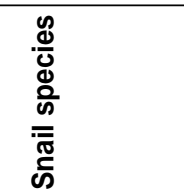 & 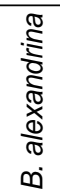 & 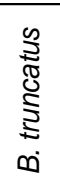 & 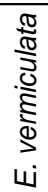 \\
\hline
\end{tabular}



and Terrestrial Pest Snails

Table 4. Values of LC 90, LC 50 and LC 25 against B. alexandrina, B. truncatus and E. vermiculata treated with Lupine NPs. and $\mathrm{CuO}_{4} \mathrm{NPS}$

\begin{tabular}{|c|c|c|c|c|c|c|c|c|c|c|c|c|}
\hline \multirow{2}{*}{$\begin{array}{c}\text { Nail } \\
\text { species }\end{array}$} & \multicolumn{6}{|c|}{ Lupine NPs } & \multicolumn{6}{|c|}{$\mathrm{CuO}_{4} \mathrm{NPs}$} \\
\hline & LC90 & LC50 & LC25 & Slope & $r$ & $\mathrm{Chi}^{2}$ & LC90 & LC50 & LC25 & Slope & $r$ & $\mathrm{Chi}^{2}$ \\
\hline $\begin{array}{c}B . \\
\text { alexandrina }\end{array}$ & 11.9722 & 4.5664 & 2.7496 & 3.0616 & 0.8972 & 47.79 & 48.2644 & 8.8869 & 3.6474 & 1.7440 & 0.96 & 2.59 \\
\hline B. truncatus & 8.382 & 3.3579 & 2.0784 & 3.2260 & 0.9972 & 2.59 & $\mathrm{Nd}^{*}$ & $\mathrm{Nd}^{*}$ & $\mathrm{Nd}^{*}$ & $\mathrm{Nd}^{*}$ & $\mathrm{Nd}^{*}$ & $\mathrm{Nd}^{*}$ \\
\hline $\begin{array}{c}E . \\
\text { vermiculata }\end{array}$ & 2.0815 & 0.5484 & 0.2718 & 2.2124 & 0.9571 & 13.1474 & $\mathrm{Nd}^{*}$ & $\mathrm{Nd}^{*}$ & $\mathrm{Nd}^{*}$ & $\mathrm{Nd}^{*}$ & $\mathrm{Nd}^{*}$ & $\mathrm{Nd}^{*}$ \\
\hline & & & & & 0.95 & 6 & & & & & 0.997 & 3.8 \\
\hline
\end{tabular}

$\mathrm{Nd}^{*}$ the Ldp line program didn't estimate these values because there were no enough mortalities that needed to make the regression lines.

\section{CONCLUSSION}

The present study represents the first toxicological tests of lupine coated with copper NPs on the terrestrial and aquatic snails. Using lupine extract to reduce the amount of metal, consequently the side effect of metal nanoparticles on environment simultaneously gaining its toxicological effect on the harmful snail pests.

Both lupine extracts NPs and copper sulphate NPs may have a sterilized effect. When $B$. alexandrina and $B$. truncatus snails exposed to sub lethal doses they didn't laid any egg masses after treatments.

\section{List of abbreviation}

\begin{tabular}{|c|c|}
\hline GNPs & : Gold nanoparticles \\
\hline Hpd & : Hematoporphyrin \\
\hline HpdGNPs & $\begin{array}{l}\text { : Hematoporphyrin coated } \\
\text { Nanoparticles }\end{array}$ \\
\hline ENPs & : Engineered Nanoparticles \\
\hline Mdm & : Mole/decimeter \\
\hline NPs & : nanoparticles \\
\hline NMs & : nanomaterials \\
\hline $\mathrm{W} / \mathrm{M}^{2}$ & : Watt /square meter \\
\hline hrs & : hours \\
\hline $\mathrm{CuSO}_{4} .5 \mathrm{H}_{2} \mathrm{O}$ & : Copper Sulphate \\
\hline $\mathrm{C}_{6} \mathrm{H}_{10} \mathrm{O}_{5}$ & : Starch \\
\hline $\mathrm{C}_{6} \mathrm{H}_{12} \mathrm{O}_{6}$ & : Glucose \\
\hline B. alexandrina & : Biomphalaria alexandrina \\
\hline B. truncatus & : Bulinus truncatus \\
\hline Zn NPs & : Zink nanoparticles \\
\hline
\end{tabular}

\section{REFERENCES}

Ali D., Yadav P.G., Kumar S., Ali H., Alarifi S. and Harrath A.H. 2014. Sensitivity of freshwater pulmonate snail Lymnaea luteola L., to silver nanoparticles. Chemosphere, 104, 134140.

Ali S.M., Yousef N.M.H. and Nafady N.A. 2015. Application of Biosynthesized Silver Nanoparticles for the Control of Land Snail Eobania vermiculata and Some Plant Pathogenic Fungi, Hindawi Publishing Corporation J. of Nanomaterials Volume 2015, Article ID 218904, 10 p. http://dx.doi.org/10.1155/2015/218904

Azzam K.M. and Tawfik M.F.S. 2005. Survey of terrestrial and aquatic malacophagous insects in certain Governorates in Egypt. Egypt. J. Biol. P. Control, 15(2), 89-92.

Azzam K.M. and Abd El-Hady E.A. 2018. Survey on terrestrial molluscs and parasitic nematodes as bio control agents in some Governorates. Menoufia J. Plant. Prot., 3 (2), 45-52.

Barker G.M. 2002. Molluscs as crop pests. CABI Publishing, Wallingford, UK. 468 p.

Bernot R.J. and Brandenburg M. 2013. Freshwater snail vital rates affected by non-lethal concentrations of silver nanoparticles. Hydrobiologia, 714(1), 25-34.

Besnaci S., Bensoltane S. Braia F.M.H., Zerari L., Khadri S. and Loucif H. 2016. Embryotoxicity evaluation of iron oxide $\mathrm{Fe} 2 \mathrm{O} 3$ on land snails: Helix aspersa. J. of Entomology and Zoology Studies, 4(4), 317-323. 
Boverhof D.R., Bramante C.M., Butala J.H., Clancy S.F., Lafranconi M., West J. and Gordon S.C. 2015. Comparative assessment of nanomaterial definitions and safety evaluation considerations. Regulatory Toxicology and Pharmacology, RTP, 73(1), 137-50. doi:10.1016/j.yrtph.2015.06.001.

Burke D.J., Pietrasiak N., Situ S.F., Abenojar E.C., Porche M., Kraj P. and Samia A.C.S. 2015. Iron Oxide and Titanium Dioxide Nanoparticle Effects on Plant Performance and Root Associated Microbes. Int. J. of Molecular Sci., 16(10), 23630-23650. doi:10.3390/ijms 161023630

Desoky A.E.A.S.S. 2018. Identification of terrestrial gastropods species in Sohag Governorate, Egypt. Archives of Agric. and Environmental Sci., 3(1), 45-48. doi:10.1039/c2nr32447d.

El-Hommossany K. and El-Sherbibni S.A. 2011. Impact of the photosensitizers hematoporphyrin coated gold nanoparticles on Biomphalaria alexandrina snails. Open J. of Animal Sci., 1(2), 54-60.

EI-Tarky A.G.S. 2005. Semi field studies to control Schistosomiasis free larval stages and its snail vectors using selected sensitizers with sunlight and laser radiation. Ph.D. Thethis, National Institute of Laser Enhanced Sci., Cairo Univ., Cairo, Egypt.

Fahmy S.R., Abdel-Ghaffar F. Bakry F.A. and Sayed D.A. 2014. Ecotoxicological Effect of Sub lethal Exposure to Zinc OxideNanoparticles on Freshwater Snail Biomphalaria alexandrina. Arch Environ Contam Toxicol, 67, 192-202.

Fernandes T.C., Christofi N. and Stone V. 2007. The environmental implications of nanomaterials. In: Monteiro-Riviere, N., Lang, T.C. (Eds.), Nanotoxicology: Characterization, Dosing and Health Effects. CRC, Boca Raton, FL, USA, pp. 405-420.

Godan D. 1983. Pest slugs and snails, biology and control. Verlage, Berlin,422 p.

Grazyna A.P., Joanna C. and Ibrahim M.B. 2014. Bio surfactant mediated biosynthesis of selected metallic nanoparticles. Int. J. Mol. Sci. 15(8), 13720-13737.

Griffitt, Arber, D.A.S.B. 2008. Effects of particle composition and species on toxicity of metallic Nanomaterials in Aquatic Organisms. 27(9), 1972-1978.
Ismail A.A., El-Massry S.A.A., Khattab M.M. and Hassan A. 2003. Daily activity and damage caused by Eobania vermiculata Müller (Gastropoda) in citrus orchards. Egyptian J. of Agric. Research, 18, 1-6.

Karima M. Azzam and Belal M.H. 2006. Screening of nematodes isolated from aquatic snails and their potential as bio-control agents of snails. Bull. Fac. Agric., Cairo Univ., 57, 185192.

Karima M. Azzam, Abd El-Razek E.A. and Metwally F. 2014. Effect of ethanolic lupine seed extract on aquatic and terrestrial snails. Egypt. J. Biol. P. Control, 24(1), 151-155.

Khidr E.K. 2018. Chitosan and Nano-Chitosan Efficacy Against the Land Snails Eobania vermiculata and Monacha obstructa (Muller) Under Laboratory Conditions., Egypt. Acad. J. Biolog. Sci., 10(2), 15-25.

Lahiani M.H., Dervishi E., Chen J., Nima Z., Gaume A., Biris A.S. and Khodakovskaya M.V. 2013. Impact of carbon nanotube exposure to seeds of valuable crops. ACS Applied Materials \& Interfaces, 5(16), 7965-7973. doi:10.1021/am402052x

Lardans V. and Dissous C. 1998. Snail control strategies for reduction of Schistosomiasis transmission. Parasitology Today, 14, 413417.

Musee N., Oberholster P.J., Sikhwivhilu L. and Botha A.M. 2010. The effects of engineered nanoparticles on survival, reproduction, and behavior of freshwater snail, Physa acuta (Daparnaud, 1805), Chemosphere, 81(10), 1196-1203.

Ragheb M. 2009. Histological studies on the effect of gold nanoparticles on Scistosoma haematobium intermediate host (Bulinus truncatus snails). MSc. Thesis, Zoology Dept., Fac. of Sci., Cairo Unive., Cairo, Egypt.

Saddik S., Afifi M. and Abu Zinzda O.A. 2017. Effect of Zinc nanoparticles on oxidative stressrelated genes and antioxidant enzymes activity in the brain of Oreochromis niloticus and Tilapia zillii. Saudi J. of Biological Sci., 24, 16721678.

Shaldoum F.M., Zayed K.M., Azzam A.M., Sharaf El-Din A.T. and Abou-Sennam F.M. 2016. Immunological Effect of Cu2O Nanoparticles on Biomphalaria alexandrina Snail the Intermediate Host of Schistosoma mansoni in Egypt. Current Sci. Int., 5(1), 92-102. 

and Terrestrial Pest Snails

Suresh A.K., Pelletier D.A. and Doktycz M.J. 2013. Relating nanomaterial properties and microbial toxicity. Nanoscale, 5(2), 463-474.

Tali D. 2009. Synthesis of uniform silver nanoparticles with a controllable size. Materials Letters 63, 2236-2238.

Tang S., Wang M., Germ K.E., Du H.M., Sun W.J., Gao W.M. and Mayer G.D. 2015. Health implications of engineered nanoparticles in infants and children. World J. of Pediatrics, WJP, 11(3), 197-206. doi:10.1007/s12519-0150028-0.
Thursby G.B., Heltshe J. and Scott K.J. 1997. Revised approach to toxicity test acceptability criteria using a statistical performance assessment. Environ. Toxicol. Chem. 16, 13221329.

Van Aken B. 2015. Gene expression changes in plants and microorganisms exposed to nanomaterials. Current Opinion in Biotechnology, 33, 206-219. doi:10.1016/j.copbio.2015.03.005.

Wong S.W., Leung K.M. and Djurišić A.A. 2013. Comprehensive review on the aquatic toxicity of engineered nanomaterials. Reviews in Nanoscience and Nanotechnology, 2(2), 79105. 


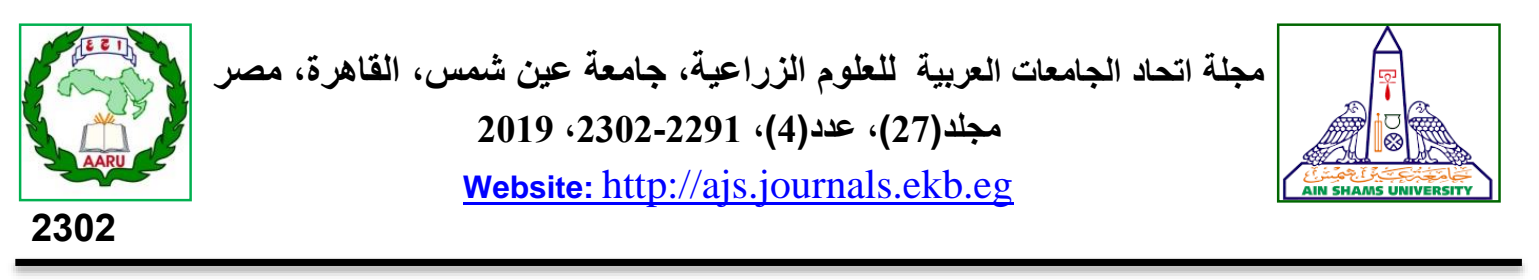

تأثير الأجزاء النانومترية المغلفة بالنحاس لمستخلص الترمس على بعض

\title{
القواقع المائية والأرضية
}

[182]

\author{
كريمة محمود عزام" - إيمان عبد الهادى - إيمان كامل خضر

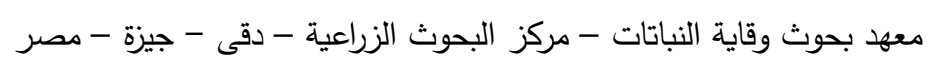

*Corresponding author: mnmn7733@yahoo.com

Received 25 June, 2019

Accepted 9 October, 2019

من 1,25 إلى 20 جزء فى المليون سواء في حالة

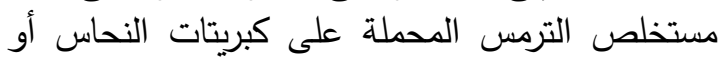

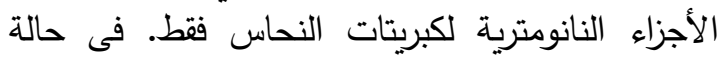

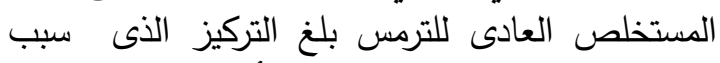

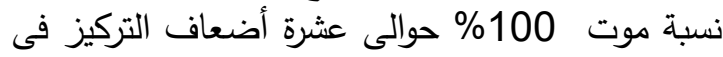

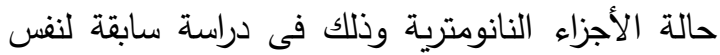

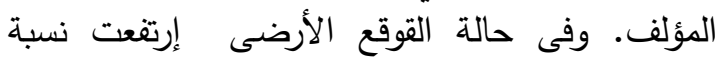
الموت من 20\% إلى 93.33\% مع كع زيادة تركيز مستخلص الترمس المحملة على كبريتات النحاس النحاس من 0,5 \% إلى 2\% . أما الأجزاء النانومترية لكبريتات

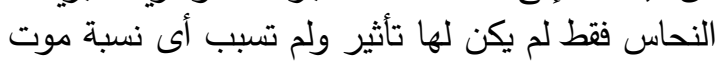
لاللقوقع الأرضى. تم مقارنة إنتاج البيض لقواقع سليمة وغير معرضة

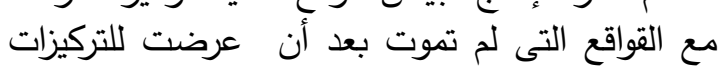

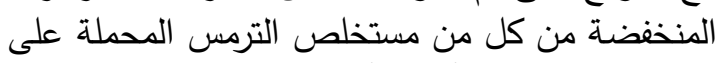

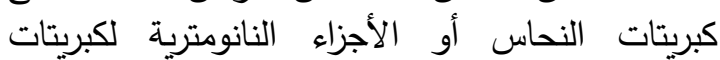

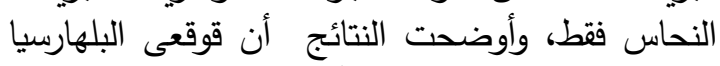

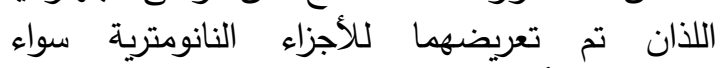

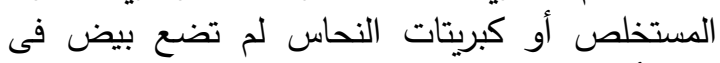

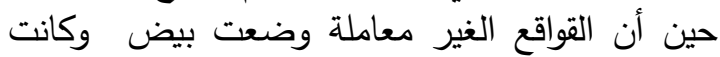

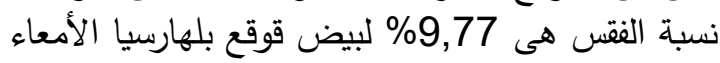

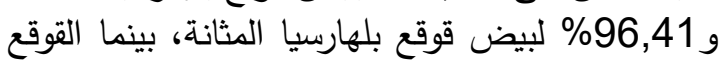

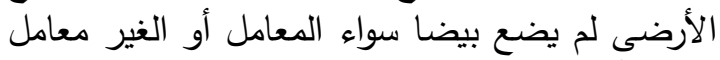

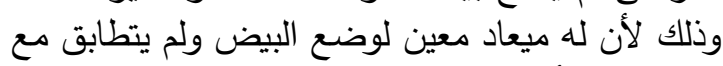
الوقت الانى أجريت فيه التجربة.

الكلمات الدالة: جزيئات الترمس، النانومترية، القواقع المائية، الواقع الأرضيّ جزئات

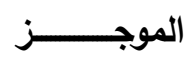

تم دراسة تأثير الأجزاء النانومترية المغلفة بكبريتات النحاس لكستخلص نبات الترمس الكصرى على العائل نhrenberg

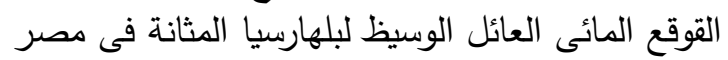
Bulinus truncatus Audouin

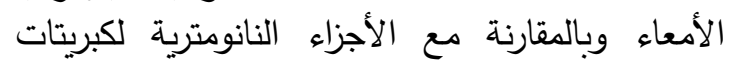
Eobania vermiculata Müller الأرضى النحاس فقط والمستخلص العادى لنبات

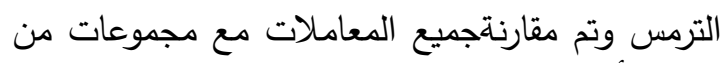
الثلاث أنواع من القواقع غير معاملة ككونترول. صمدت هذه التجربة لتوضيح الخصائص الإبادية

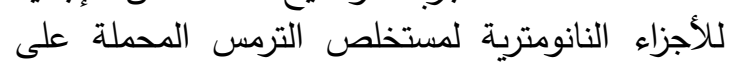
كبريتات النحاس كمبيد للقواقع السابق ذكرها، بعد مدة لتحن

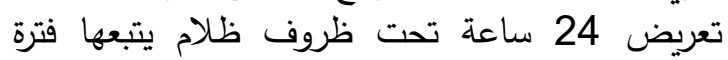
إنعاش لددة 48 ساعة تحت ظروف طراعت إضاءة عادية.

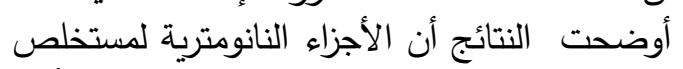

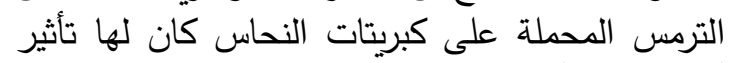

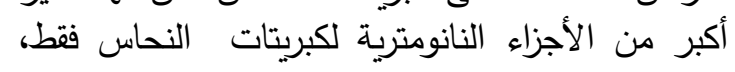

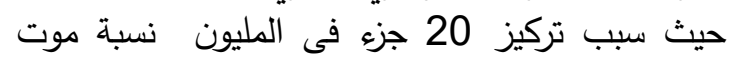
100 تحت الظروف السابق ذكرها لقوقعى بلهاررسيا

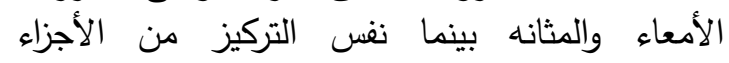

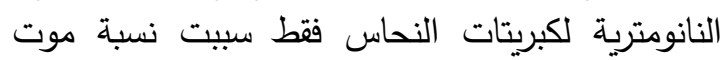

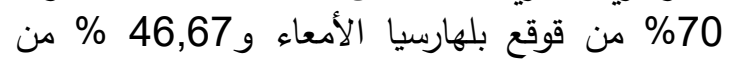

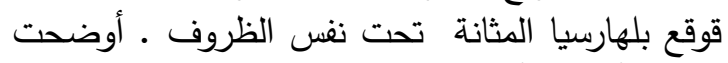
النتائج أيضا أن نسبة الموت تزدياد معن الطروف زيادة التركيز

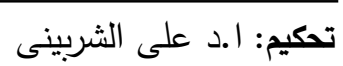

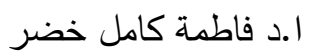


